\title{
SERBIAN PORK MARKET ANALYSIS
}

\author{
Marija Jeremic ${ }^{1}$, Koviljko Lovre ${ }^{2}$, Bojan Matkovski ${ }^{3}$ \\ *Corresponding authorE-mail: knezevicm@ef.uns.ac.rs
}

A R T I C L E I N F O
Original Article
Received: 21 September 2018
Accepted: 01 December 2018
doi:10.5937/ekoPolj1804449J
UDC 339.13.017:637.5'64(497.11)

Keywords: Market, Supply, Demand, Pork, Cobweb.

JEL:Q11

\begin{abstract}
A B S T R A C T
Pig farming is the second most important branch of livestock production according to value of agricultural production, while pork meat is the most widely eaten meat in Serbia. As the one of the characteristics of pig market is cyclicality in the movement of production volumes and prices which can influence on the imbalance in supply and demand and in price fluctuations, the main aim of this paper was to analyse pork market in Serbia. Namely, in order to identify factors that influenced pork supply and demand, and to determine the presence of cyclical oscillations on pork market, pork market in Serbia was analyzed with supply and demand functions and with Cobweb model. The results indicated that factors which influenced on demand for pork were: personal consumption, retail price of pork and beef. On the other hand, on the supply side the most important factor was the price of pork. The results also indicated that in analyzed period in Serbia existed convergent type of Cobweb model.
\end{abstract}

(C) 2018 EA. All rights reserved.

\section{Introduction}

Pig farming is a significant branch of agriculture in Serbia. Namely, according to the share in the total value of agricultural production, pig farming is the second most important branch of livestock production in Serbia, after cattle breeding. Also, from the aspect of production and consumption, pork is the most important category of meat. In the period from 2004 to 2015, pork meat was the major type of meat accounting for $57.6 \%$ of total meat production. Also, pork meat is the most widely eaten meat in Serbia with an average annual consumption of $27.5 \mathrm{~kg}$ per capita followed by poultry $(11 \mathrm{~kg}$ per capita per year) beef ( $8.2 \mathrm{~kg}$ per capita per year), sheep and goat meat $(2.5 \mathrm{~kg}$ per

1 Marija Jeremić, Ph.D, Teaching Assistant, University of Novi Sad, Faculty of Economics in Subotica, Segedinski put no. 9-11, 24000 Subotica, Republic of Serbia, Phone +381 24628 065, E-mail: knezevicm@ef.uns.ac.rs

2 Koviljko Lovre, Ph.D, Full Professor, University of Novi Sad, Faculty of Economics in Subotica, Segedinski put no. 9-11, 24000 Subotica, Republic of Serbia, Phone +381 21485 2911, E-mail: klovre@ef.uns.ac.rs

3 Bojan Matkovski, Ms.C, Teaching Assistant, University of Novi Sad, Faculty of Economics in Subotica, Segedinski put no. 9-11, 24000 Subotica, Republic of Serbia, Phone +381 24 628 049, E-mail: bojan.matkovski@ef.uns.ac.rs

http://ea.bg.ac.rs 
capita per year) (FAOSTAT, 2017). The actual consumption of pork in Serbia is probably higher. Namely, pig slaughtering in places other than slaughterhouses (for example, family farms) for own consumption is very widespread. Therefore, data on the number of slaughtered pigs, pork production and consumption are rather underestimated than real data (FAO, EBRD 2007; FAO, 2009).

Pig production in Serbia had a growing trend until the mid-1980s. After that the number of pigs was in constant decline (Popović, Knežević, Štavljanin, 2010). In Serbia, there are about 3.5 million pigs and 355 thousand pig farms. Since 2000, the number of pigs in Serbia have decreased by $30 \%$, while the number of sows has almost halved. In Serbia in the period from 2004 to 2015 the average rate of fall in the number of pigs was $1.2 \%$ per year. Also, in the same period the number of sows decreased at an average annual rate of $5.7 \%$. The past period was very unfavourable for pig farmers. Namely, due to frequent cycles of the livestock market, pig farmers made significant losses (Jeremić, Zekić, Matkovski, 2015).

One of the characteristics of pig market is cyclicality in the movement of production volumes and prices. Cyclical movements of production in the agricultural sector are manifested by the imbalance in supply and demand and in price fluctuations, which is the case with the pork market. Therefore, having in mind retrograde tendencies and cyclical movements in pork market the basic objective of the paper is to evaluate the functions of supply and demand of pork in order to identify the factors that in the previous period influenced the supply and demand for pork. On the other hand, the other goal was to determine the presence and type of cyclical movements on pork market in Serbia.

\section{Materials and methods}

A demand for a product represents the total amount of products that customers are willing to buy. Demand for pork fluctuates and depends on the many factors (Lâm et al., 2013). Numerous factors (economic, health, cultural, religious, and the like) affect population demand for pork. However, only some of the factors are measurable. In this paper, only quantifiable factors were used and those factors are: price of pork, prices of other types of meat (substitute), data on personal consumption of the population and the number of inhabitants. According to Bielik and Šajbidrova (2009) the demand of population is the most important factor which influence on the amount of the production and on supply. Therefore, the assumption used to evaluate pork demand function is that the domestic population consumption of pork approximates the demand for it.

In this paper, the following demand elasticity coefficients were analyzed: the demand elasticity coefficient in relation to personal consumption (income elasticity of demand), the price elasticity of demand (direct and cross), and the elasticity coefficient of demand in relation to the change in the number of inhabitants.

The function of pork demand is assessed by the method of ordinary least squares in the logarithmic-linear form: 


$$
\ln D_{t}=\ln \alpha+\beta_{1} \ln P_{t}+\beta_{2} \operatorname{lnP}_{t}+\beta_{3} P_{p m}+\beta_{4} \operatorname{lnPbm}_{t}+\beta_{5} \operatorname{lnPcm}_{t}+u_{t}
$$

where: $\mathrm{D}_{\mathrm{t}}$ - population demand for pork; $\mathrm{P}_{\mathrm{t}}$ - population number; $\mathrm{Pc}_{\mathrm{t}}$ - real personal consumption ${ }^{4}, \mathrm{Ppm}_{\mathrm{t}}$ - real retail pork price, $\mathrm{Pbm}_{\mathrm{t}}$ - real retail beef price; $\mathrm{Pcm}_{\mathrm{t}}$ - real retail price of chicken meat; $\alpha$ - constant, $\beta_{1}, \beta_{2}, \beta_{3}, \beta_{4}, \beta_{5}$ - parameters of the function, $\mathrm{u}_{\mathrm{t}}$ - stochastic variable. The parameters of the function also show certain elasticity coefficients. That is, the parameter next to the population $\beta 1$ is the elasticity coefficient of demand in relation to the population. The parameter next to personal consumption, $\beta 2$, represents the coefficient of demand elasticity in relation to personal consumption (income elasticity of demand). The parameter $\beta 3$, is a direct price elasticity of demand. Parameters with retail prices of beef and chicken meat, $\beta 4$ and $\beta 5$, represent the coefficients of cross-elasticity of demand. More precisely, the parameters $\beta 4$ and $\beta 5$ show the cross-price elasticity of the demand of the substitutes.

The production and supply of agricultural products are determined by numerous economic and non-economic parameters, and the most important is the price of the product which affects the volume of production (Mičić et. al, 2017). The first pork supply function which was evaluated had the following form (logarithmic-linear form):

$\ln S_{t}=\ln \alpha+\beta_{1} \operatorname{lnPpm}_{\mathrm{t}-1}+\beta_{2} \operatorname{lnS}_{\mathrm{t}-1}+\beta_{3} \mathrm{~T}$

where: $\mathrm{S}_{\mathrm{t}}$ - pork supply $(\mathrm{kg})$; $\mathrm{Ppm}_{\mathrm{t}-1}$ - real pork meat price wit one lag $(\mathrm{rsd} / \mathrm{kg}) ; \mathrm{S}_{\mathrm{t}-1}$ pork supply from the previous period; T - time; $\alpha$ - constant, $\beta_{1}, \beta_{2}, \beta_{3}$ - parameters of the function.

There are different approaches for analyzing cyclical movements in agricultural production. For the purposes of this paper, the Cobweb model was used. Stephane (2008) consider that Cobweb model assume that amount of product supply in current period depends on the price lever from the last period. According to Lovre (1997), the Cobweb model is a simplified analysis of the cyclical movement in the market of a particular product, based on two variables: the relative price of the product and the amount of production. The simplest form of the Cobweb model consists of two functions, which are the function of supply and demand with the necessary condition for the equity of the quantity of demand with the quantity of supply:

$D_{t}=\alpha_{0}+\alpha_{1} P_{t}$

$\mathrm{S}_{\mathrm{t}}=\beta_{0}+\beta_{1} \mathrm{P}_{\mathrm{t}-1}$

$D_{\mathrm{t}}=\mathrm{S}_{\mathrm{t}}=\mathrm{Q}_{\mathrm{t}}$

4 In order to calculate real personal consumption GDP deflator was used. Namely, by using the data on personal consumption at a constant price statistically insignificant results were obtained. On other hand, in order to calculate real prices of pork, beef and chicken meat price of corn is used. Namely, prices of pork, beef and chicken meat was deflated by average purchase prices of corn, as the most important component of fodder. 
where: $D_{t}$ - demand in time $t ; S_{t}$ - supply in time $t ; Q_{t}$ - equilibrium quantity in time $t$; $\mathrm{P}_{\mathrm{t}}$ - price of product in time $\mathrm{t} ; \mathrm{P}_{\mathrm{t}-1}$ - price of product in time $\mathrm{t}-1 ; \alpha_{0}, \alpha_{1}, \beta_{0}, \beta_{1}$ - parameters of the function.

Flexibility of prices and quantity around the equilibrium and the character of oscillations depend on the relationship of parameters $\beta_{1} / \alpha_{1}$. In linear supply and demand functions the estimated parameters are theoretically correct if $\beta_{1}>0$ and $\alpha_{1}<0$. The absolute values of these parameters determine the fluctuations in prices and quantity around the equilibrium, and indicate whether these quantities will converge, diverge, or oscillate in the same direction.

The empirical research of the supply, demand functions and Cobweb model include the time period from 2004 to 2015, and the data are given on an annual basis. The time period covered by the analysis is determined by the availability of data. The price data are shown as real data 5 .

\section{Results and discussions}

\section{Production and trade performances of pork meat in Serbia}

The pork is major type of meat produced in Serbia (Figure 1.). In the period from 2004 to 2015, average production of pork meat was 261 thousand tons, followed by beef, poultry and sheep meat with average production of 87,82 and 24 thousand tons, receptively. According to Petrović et al. (2013) besides a number of important characteristics of pigs, one of them, which is different from other domestic animals is a considerable amount of meat that can be produced per sow per year (more than 2,000 $\mathrm{kg}$ of live weight of fatteners or over $1,600 \mathrm{~kg}$ of carcass sides or more than $800 \mathrm{~kg}$ of meat).

In the observed period, the total production of pork was growing at a very small average annual rate of $0.34 \%$, and ranged from 240 to 290 thousand tons. The lowest pork meat production was recorded in 2004, when the production of pork reached the level of 242 thousand tons. On the other hand, the maximum production was realised in 2007 (287 tons), after which the pork production was constantly decreasing. According to Mijić, Zekić, Jakšić (2016) those tendencies are more or less in correlation with the movement of the number of livestock units.

5 In the case of demand function and Cobweb model as data sources, the following were used: Statistical Yearbooks of the Republic of Serbia for data on the average annual retail price for pork, beef and chicken meat, personal consumption and the number of inhabitants. On the other hand, in the case of a supply function and Cobweb model, as a sources of data the following were used: Statistical Yearbooks of the Republic of Serbia for data on the average annual retail price of pork; Database of the Statistical Office of the Republic of Serbia for data on the supply of pork and the price of corn. 
Figure 1. Meat production in Serbia

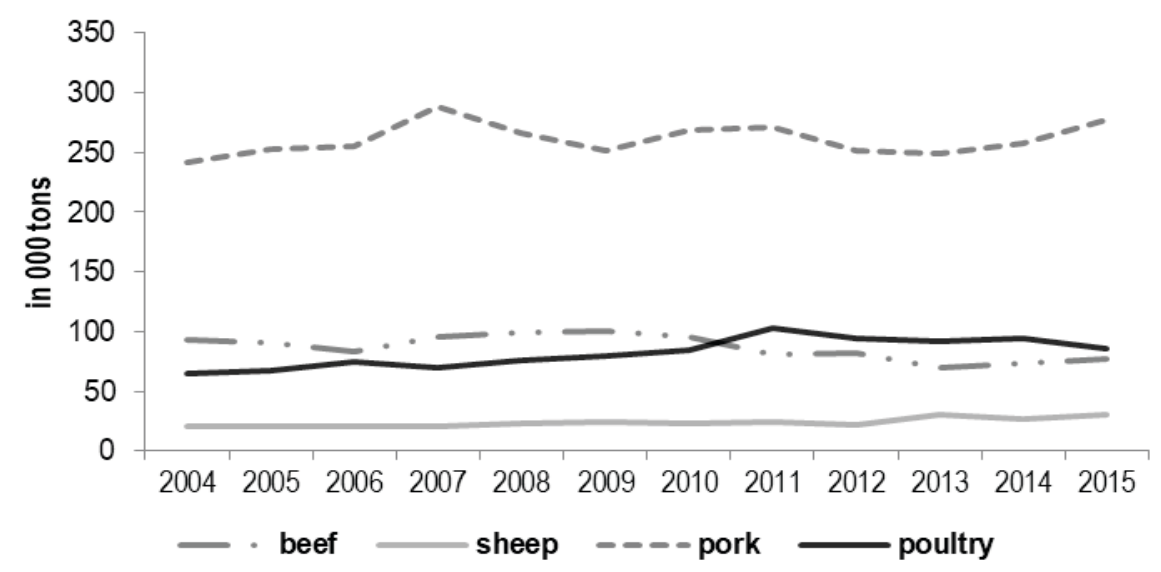

Source: Statistical Office of the Republic of Serbia, 2017

As the foreign trade flows of pork are concerned, in the analyzed period pork export increased and the largest share of pork export in total export was in 2014 (Figure 2.). The value of export in 2014 in relation to 2004 rose nominally from USD 20.8 thousand to USD 58 million. This growth of pork export is the result of an increase in exports to the Russian Federation. In the same period the import of pork was also constantly increasing, and reached its maximum level in 2014. Until 2014, Serbia had negative pork meat foreign trade balance. Large amounts of a pork import had negative influence on domestic production and on pig farmers. In 2014, when Serbia exported a significant part of domestic production to Russia, in order to meet domestic demand, pork import increased. The most important import market in that year was Spain. Namely, compared to 2013 when the value of pork import was USD 18.1 million, in 2014 pork import from Spain increased to USD 30.2 million.

Figure 2. Pork net trade in Serbia

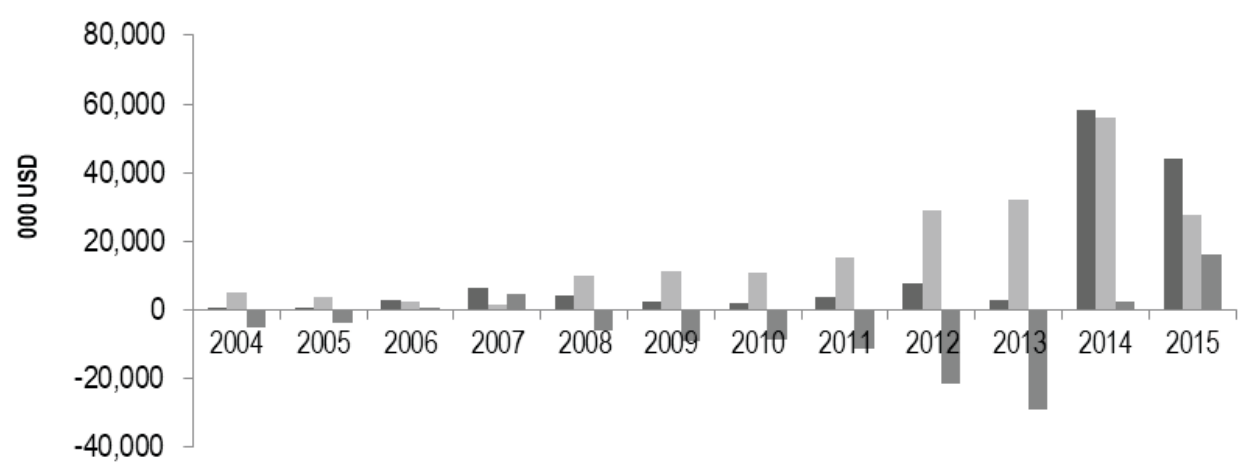

Export $\square$ Import $\quad$ Net trade

Source: Statistical Office of the Republic of Serbia, 2017 
Foreign trade liberalization influenced by free trade agreements with European Union, CEFTA countries and Russia had effects on foreign trade of Serbian products and its positions on foreign market. According to some previous researches which analyzed liberalization effects and level of comparative advantages in Serbia, results showed that meat and meat products had comparative advantages on international market, but with negative tendencies (Matkovski, Lovre, Zekić, 2017), while on market of Western Balkan countries, meat and meat products had comparative advantages in all countries, except Croatia (Birovljev, Matkovski, Ćetković, 2015). Potential consequences of Serbian foreign integration in future will be international competition, while prices of pigs and pig meat will probably decrease more than cost of inputs. Answer to this situation will be necessity to reduce production costs (first of all cost of food and piglets) which can be achieved through technological improvement, lower variable and fixed costs (Petrović, 2005). Additionally, increasing the competitiveness of Serbian livestock production can be achieved by creating the conditions for the market environment through investment, both in knowledge and in equipment. Therefore, structural and institutional measures, and measures of credit support should be the main instruments for achieving this goal (Petrović et al., 2013).

\section{Pork meat demand function analysis}

Based on the empirical analysis of the pork demand function, it is possible to determine the direction and intensity of the relationship between the demand for pork and the factors that affect it. More precisely, the estimated elasticity coefficients indicate the implications of the basic laws in the population demand for pork, in the analyzed period.

Table 1. Results of the evaluation of the pork meat demand function

\begin{tabular}{|l|l|l|}
\hline \multicolumn{1}{|c|}{ Parameters } & t statistic & Probability (P) \\
\hline$\alpha=-3.29255$ & -0.682804 & 0.5202 \\
\hline$\beta_{1}=1.868097$ & 1.780496 & 0.1253 \\
\hline$\beta_{2}=0.369692$ & 3.201743 & 0.0186 \\
\hline$\beta_{3}=-0.194738$ & -1.208806 & 0.0315 \\
\hline$\beta_{4}=0.43919$ & 2.550394 & 0.0435 \\
\hline$\beta_{5}=-0.396881$ & -2.791444 & 0.2722 \\
\hline$R^{2}$ & 0.76474 & \\
\hline $\mathrm{DW}$ & 1.94 & \\
\hline $\mathrm{n}$ & 12 & \\
\hline
\end{tabular}

Source: The author's calculation

Based on the probability value (Table 1.), it can be concluded that, in the observed period factors which affected on the pork demand were: personal consumption, retail prices of pork and beef. The parameters $\beta_{1}$ and $\beta_{5}$ are statistical insignificant. 
Another analyzed coefficient is the demand elasticity coefficient in relation to personal consumption that is the coefficient of income elasticity of demand. Its value is 0.37 . As this coefficient has the corresponding sign and value significantly lower than 1 , it can be concluded that the demand for pork is inelastic in relation to personal consumption. In other words, the income elasticity of demand for pork in Serbia is very low, which means that, in the analyzed period, the increase in personal consumption was faster than the demand for pork. The low elasticity of meat demand relative to personal consumption can be explained by the fact that the meat is the product belonging to the category of necessary products. In other words, pork consumption in Serbia has probably reached a high level of saturation.

Coefficient of direct price elasticity of demand is -0.19 . As in the previous case, this coefficient has the expected sign, which is in line with the demand theory. However, given the very low value of this coefficient, it can be concluded that demand for pork is extremely inelastic. That means that the consumption of pork is relatively stable in terms of price change. According to theory, demand for certain products is more elastic in relation to price if there are a number of substitutes for that product. In Serbia, after consumption of pork, the highest are the consumption of chicken and beef meat. The consumption of other types of meat on an annual level (such as goat, sheep) is negligible. It can be concluded that another reason for low price elasticity of demand for pork is a small number of substitutes. In other words, eating habits of the population are the most important factor of a stable level of pork consumption.

The coefficient of cross-elasticity of demand for pork in relation to the price of beef is 0.44 . The positive value of this coefficient implies that beef meat and pork are substitutes. However, its relatively low value indicates the relatively inelastic demand for pork in relation to the price of beef. In other words, the substitution of demand between pork and beef has no significant economic character, but consumer preferences dominate. That means, the prices of substitutes or other types of meat did not significantly affect the demand for pork.

\section{Pork supply function analysis}

As the estimation of the initial model obtained statistically insignificant results, several variants of model were evaluated in which certain independent variables were excluded in order to obtain a model that would be acceptable. Also, in different variants of pork supply function, independent variable price of pork meat included different length of time lag $\left(\mathrm{Ppm}_{\mathrm{t}-1}, \mathrm{Ppm}_{\mathrm{t}-2}\right)$.

Selected pork supply function which had statistically the most significant indicators had the logarithmic-linear form:

$\ln S_{\mathrm{t}}=\ln \alpha+\beta_{1} \operatorname{lnPpm}_{\mathrm{t}-2}+\beta_{2} \mathrm{~T}$

where: $\mathrm{S}_{\mathrm{t}}$ - pork supply $(\mathrm{kg}) ; \mathrm{Ppm}_{\mathrm{t}-2}$ - real price of pork with two lags; $\mathrm{T}$ - time; $\alpha$ constant, $\beta_{1}, \beta_{2}$ - parameters of the function. 
When evaluating the selected supply function, the method of the least ordinary squares is used.

Table 2. Results of the evaluation of the pork meat supply function

\begin{tabular}{|l|l|l|}
\hline \multicolumn{1}{|c|}{ Parameters } & t statistic & Probability (P) \\
\hline$\alpha=4.056088$ & 27.66801 & 0.0000 \\
\hline$\beta_{1}=0.126419$ & 4.425925 & 0.0031 \\
\hline$\beta_{2}=0.005128$ & 1.756209 & 0.1225 \\
\hline $\mathrm{R}^{2}$ & 0.737791 \\
\hline $\mathrm{DW}$ & 1.72 \\
\hline $\mathrm{n}$ & 12 \\
\hline
\end{tabular}

Source: The author's calculation

Coefficient of elasticity of pork supply in relation to price, i.e. the price elasticity of the supply (Table 2.) is extremely low (0.126). Namely, the low price elasticity of pork supply can be explained by the fact that it takes a certain period of time to get pork meat as a final product from the fattening pigs. Therefore, the possibility of adjusting production volume to the current price changes is relatively limited. Also, another reason for the low price elasticity of the supply of pork is the difficult storage of products derived from livestock breeding. That is, slaughtering of pigs can be delayed only for several weeks due to the consequences it leaves on the quality of the produced meat. Therefore, the production of fatteners becomes unprofitable because a certain price is paid for each weight class. That means that the fattening pigs must be sold at a certain moment at a given market price and in the case of rising prices of pork, farmers are not able to influence the growth of supply through livestock stock.

\section{Analysis of the market of the product with the cyclical movements}

According to Matsumoto and Szidarvszky (2015) Cobweb explains why and how certain types of market give rise to fluctuations in prices in quantities, with its mainly focus on agricultural markets. Pork market is one of the best examples of such market. Namely, a specific fluctuation mechanism is one of the most important characteristic of the pork market. The length of the cycle can be divided into characteristic phases, which are repeated over time. The "cycle of pigs" is characterized by the following five phases: in the first stage, the supply of pork is below average, while the price is above the average, and there is no increase in the number of pigs. The second phase is characterized by an increase in supply and a fall in price towards equilibrium. As a result of the high price from the previous period the number of pigs is increasing. In the third stage, there is a rise in supply (due to the delivery of the above-mentioned surplus in the number of pigs from the second phase) and the price drops towards the equilibrium level. Also, as a result of falling prices from the previous phase, in the third phase of the cycle, the number of pigs is reduced. After that, in the fourth phase, the 
reduction in supply from the previous period decreases, and the price is rising again. In the fifth phase, which at the same time represents the beginning of the new cycle, the supply falls below the minimum, the price rises above the maximum, and the number of pigs grows to a normal level. In the case of a pig cycle, there is a reverse proportion of variation in the amount of supply and the relative price of pork. Also, the variations in the quantity of supply are far less than the variation in prices, which indicates of the relatively inelastic demand for pork.

In the case of the Cobweb model several variants of the model were also evaluated. Namely, the Cobweb model can be assessed for both the pork market and the market for fattening pigs, as was the case in this paper. Also, apart from the fact that the Cobweb model was evaluated for both (for pork and fattening pigs markets), the variants of the model were tested for the independent variable in the supply function, including the price of pork with one or two lags.

However, as the results of other models had statistically insignificant results, the model accepted in the work relates to the pork market, and the price of pork that is included as an independent variable in the supply function is included with two lags.

In this paper, the Cobweb model for pork meat has the following form:

$\mathrm{S}_{\mathrm{t}}=\beta_{0}+\beta_{1} \mathrm{Ppm}_{\mathrm{t}-2}+\beta_{2} \mathrm{~T}$

$\operatorname{Ppm}_{\mathrm{t}}=\alpha_{0}+\alpha_{1} \mathrm{D}_{\mathrm{t}}+\alpha_{2} \mathrm{~T}$

$D_{\mathrm{t}}=\mathrm{S}_{\mathrm{t}}=\mathrm{Q}_{\mathrm{t}}$

The Cobweb model for the pork market in Serbia was calculated using the two stage least square method. Namely, due to the problem of identification of the Cobweb model, in case of empirical evaluation of the model it is necessary to simultaneously treat the supply and demand functions. More precisely, in order to obtain an impartial estimation of the model, the equations of the Cobweb model are evaluated at once using the two stage least square method. An impartial estimation of the model is achieved in such a way that the actual value of the quantity of demand in the inverse demand function is replaced by the estimated value of the quantity from the equation 7 . The results of the evaluation of the supply function and inverse demand function estimates are shown in the following tables (Table 3. and Table 4.).

Table 3. Results of the evaluation of pork meat supply function

\begin{tabular}{|l|l|l|}
\hline \multicolumn{1}{|c|}{ Parameters } & t statistic & Probability (P) \\
\hline$\beta_{0}=90.90403$ & 19.73476 & 0.0000 \\
\hline$\beta_{1}=0.115447$ & 4.619536 & 0.0024 \\
\hline$\beta_{2}=0.605694$ & 1.926569 & 0.09524 \\
\hline
\end{tabular}

Source: The author's calculation 
Table 4. Results of the evaluation of the inverse pork meat demand function

\begin{tabular}{|l|l|l|}
\hline \multicolumn{1}{|c|}{ Parameters } & t statistic & Probability (P) \\
\hline$\alpha_{0}=732.0682$ & 3.747067 & 0.0072 \\
\hline$\alpha_{1}=-5.364807$ & -3.019623 & 0.0194 \\
\hline$\alpha_{2}=-4.921491$ & -2.139417 & 0.0697 \\
\hline
\end{tabular}

Source: The author's calculation

Pork meat demand function derived from inverse pork meat demand function:

$$
D_{t}=136,478-0,186 \text { Psm }_{t}-0,917 T
$$

Estimated parameters in the equations of the Cobweb model can theoretically be accepted as correct because the regression coefficient in the demand function $\left(\beta_{1}\right)$ is negative, while the regression coefficient in the supply function $\left(\alpha_{1}\right)$ is positive. By absolute size, the regression coefficient in the demand function is greater than the regression coefficient in the supply function. In other words, because is $|-0.186|>$ $|0.1154|$, it can be concluded that the slope of the demand curve is greater than the slope of the supply curve. This means that in the case of pork meat market in Serbia, exists convergent case of the Cobweb model.

An increase in the quantity of products on the market in the inverse function of demand affects the reduction of the relative price in the same time period. Also, in an inverse demand function, the estimated parameter in the quantity has an appropriate negative sign, which means that the increase in pork production changes the relative price in the opposite direction. In the case of a demand function, the parameters (derived from inverse demand functions) also have a theoretically correct negative sign, which means that in the case of rising pork prices, the demand for the same will be reduced.

In the case of the pork market, this is an example of a Cobweb model with convergence oscillations, i.e. the oscillations are getting smaller, and since $-10.1154 /-0.186 \leq 0$ the oscillations should be settled over time. Variations in the movement of pork meat supply are less than the relative price variation, and the relatively small change in the amount of production over proportionately influences the movement of the relative price of pork. More precisely, when the quantity of pork supply increases, the relative price is below the equilibrium, while in the next period the quantity of supply is small and the relative price, due to the excess demand, is growing above equilibrium.

Such a trend is characteristic for the market where demand is relatively inelastic, and small changes in the quantity of products cause above average changes in product prices, which has already been founded for the market for pork in Serbia.

However, although it is suitable for analyzing the existence of cyclical oscillations in the markets of certain agricultural products, the Cobweb model is considered insufficient to explain complex relationships in cyclical trends in the amount of production and 
relative prices. Namely, in the Cobweb model, the market for agricultural products is treated simpler, exclusively based on data on the relative price and quantity of production. However, other factors (such as trends in the input market, trends in exports and imports, etc) act on the market of certain products, which are not specially specified in the case of Cobweb model, but are incorporated into the model by variable time. Therefore, for the analysis of more complex relations, different more comprehensive models are being constructed that overcome the mentioned disadvantages.

\section{Conclusions}

Although very important branch of livestock production in Serbia, in the analysed period, pig farming has been recording retrograde production tendencies. The retrograde tendencies are reflected in the reduced number of pigs and sows, and in pork meat production stagnation. Likewise, import of pork notably increased, which had negative impact on pig farmers. As the pork market factors are concerned, in the analyzed period, the most important factor that influenced on pork supply was pork price. On the other hand the factors that influenced on pork demand were: personal consumption, retail price of pork and beef. At the same time, on the pork market existed convergent type of oscillations which indicate that a small change in pork production volume over proportionately change relative pork price.

Bearing in mind that in analyzed period pork meat import had a significant influence on the pork and pig market, future research could be focused on models that are appropriate to explain more complex market relations.

\section{Conflict of interests}

The authors declare no conflict of interest.

\section{References}

1. Bielik, P., \& Šajbidrova, Z. (2009). Elasticity of consumer demand on pork meat in the Slovak Republic. Agricultural Economics, 55(1), 2-19.

2. Birovljev, J., Matkovski, B., \& Ćetković, B. (2015). The competitiveness of the Serbian agri-food products on the market of countries in the region. Annals of the Faculty of Economics in Subotica, 51(1), 61-78. [in Serbian: Birovljev, J., Matkovski, B., \& Ćetković, B. (2015), Konkurentnost poljoprivrednoprehrambenih proizvoda Srbije na tržištu zemalja regiona].

3. FAO (2009). Agribusiness Handbook: Red Meat. Rome: FAO

4. FAO, \& EBRD (2007). A systematic analysis of the agribusiness sector in transition economies: The Serbian meat value-chain. Retreived from: http:// www.eastagri.org/files/serbia_meat_vc_final.pdf (October 8, 2012)

5. FAOSTAT (2017). Retrieved from: http://faostat3.fao.org/home/E (April 10, 2017) 
6. Jeremić, M., Zekić, S., \& Matkovski, B. (2016). Economic characteristics of pig production in Sebia. Agrieconomica, 70, 11-18. [in Serbian: Jeremić, M., Zekić, S., Matkovski, B. (2016), Ekonomske osobenosti proizvodnje svinja u Srbiji].

7. Lâm Đ. T., Cường T.T., Huyền N.T., Xuân V.K., \& Đức N.A. (2013). Analysis of factors affecting demand for pork consumption in Vinh City, Nghe an Province. Journal of Science and Development, 11(3), 429-438.

8. Lovre, K. (1997). Ekonomski modeli u poljoprivredi. Novi Sad. Nevkoš.

9. Matkovski, B., Lovre, K., \& Zekić, S. (2017). The forign trade liberalization and export of agri-food products of Serbia. Agricultural Economics, 63(7), 331-345.

10. Matsumoto, A., \& Szidarvszky, F. (2015). The Asymptotic Behavior in a Nonlinear Cobweb Model with Time Delays. Discrete Dynamics in Nature and Society vol. 2015, Article ID 312574, 14 pages. https://doi. org/10.1155/2015/312574.

11. Mičić, I., Rajić, A., Živković, J., Orović, D., Mičić, M., Mičić, I., \& Mičić, M. (2017). Optimal flock structure of pig arm providing minimum costs. Economic of Agriculture, 64(3), 1003-1018.

12. Mijić, K., Zekić, S., \& Jakšić, D. (2016). Profitability analysis of meat industry in Serbia. Facta Universitatis: Economics and Organization, 13(4), 379-386. doi: 10.22190/FUEO1604379M

13. Petrović, M. M. (2005). Livestock production in Serbia on its way to European Union. Biotechnology in Animal Husbandry, 21(5-6), 1-7. doi: 10.2298/ BAH0506001P

14. Petrović, M. M., Aleksić, S., Petrović, M. P., Petrović, M., Pantelić, V., Novaković, Ž., \& Ružić-Muslić, D. (2013). Potentials of Serbian livestock production - outlook and future. Biotechnology in Animal Husbandry, 29(1), 1-17. doi: 10.2298/BAH1301001P

15. Popović, R., Knežević, M., \& Štavljanin, B. (2010). Development of the market for basic livestock products in Serbia in the context of European integration. Agroprivreda Srbije i evropske integracije: (Ne)prilagođenost obostranoj primeni prelaznog trgovinskog sporazuma (103-115). Belgrade: DAES (In Serbian: Popović, R., Knežević, M., \& Štavljanin, B. (2010). Razvoj tržišta osnovnih stočarskih proizvoda u Srbiji u kontekstu evropskih integracija)

16. Statistical Office of the Republic of Serbia (2004-2015). Statistical Yearbooks of the Republic of Serbia 2004-2015. Belgrade.

17. Statistical Office of the Republic of Serbia (SORS) (2017). Retrieved from: http:/webrzs.stat.gov.rs/WebSite/public/ReportView.aspx (April 15, 2017) 